\title{
Dynamics of Microorganisms' Producent Separation in Nutritional Environment
}

\author{
Zokirova Mashhura, Fayzieva Dilrabo, Zokirov Sodikjon
}

\begin{abstract}
This article is devoted to the production of fructose syrups in the fermentative method, as the object of research is the inulin topinambur plant. The chemical composition of "Mo'jiza" and "Fayz-Baraka" types of topinambur which grown in Uzbekistan has been studied compared comparatively.

Aspergillus oryzae fungus and Saccharomyces cerevisiae yeast are selected as the produtentyan of Inulinase enzyme. For these microorganisms, nutrient enzymes have been prepared to enrich the topinambur extract and topinambur extract with minerals. Microorganisms have been innoculised in these nutritional environments and found activity that biomass, fructose, protein content, as well as inulinase and protease enzymes were found every day.
\end{abstract}

Keywords - inulin, fructose, Aspergillus oryzae, Saccharomyces cerevisiae, fructose syrop, enzyme, biomass.

\section{INTRODUCTION}

Nowadays, natural sweeteners obtained from nontraditional plant raw materials such as stevia, chicory and Helianthus tuberosus are widely used in the food industry, which are used to form taste, to enrich food products with biologically active substances and to give them functional properties.

One of these sweeteners with functional properties is fructose syrup. It is a highly concentrated hydrolyzed plant extract with a mass fraction of solid substances from 50 to $75 \%$. The particular value of ftuctose syrup for patients with diabetes mellitus, reducing the need for inulin preparations and stabilizing the level of sugar in human blood [1].

Hydrolysis of topinambur (Helianthus tuberosus) inulin is one of the main methods of obtaining fructose syrup. Inulin is a natural polysaccharide, mostly consists of $95 \%$ of fructose. Polyfructosans in the molecular formula of inulin are of the same size. Its molecule consists of 30-35 monosaccharide residues, with a total molecular mass of 5000-6000, a chemical composition of which consists of - D-fructofuranose and fructose polymers, which are bonded together with $\cdot 2 \rightarrow 1$ glycoside. Hydrolysis of Jerusalem artichoke inulin is one of the main methods of obtaining fructose-glucose syrup. Inulin is hydrolyzed by inulinase enzyme or by various acids [2].

Enzymatic hydrolysis is preferable to acidic, since is more environmentally purely and does not form by-products that complicate the isolation and purification of fructose. Inulinase (2,1- $\beta$-D-fructan fructanohydrolase, EC 3.2.1.7) breaks $\beta-2,1$-bonds in the inoculum, forms fructose and

Revised Manuscript Received on July 18, 2019

Zokirova Mashhura, Tashkent Chemical-Technological Institute, Tashkent, Uzbekistan

Fayzieva Dilrabo, Tashkent Chemical-Technological Institute, Tashkent, Uzbekistan Zokirov Sodikjon, Tashkent ChemicalTechnological Institute, Tashkent, Uzbekistan fructooligosaccharides. This enzyme is used for hydrolyzing the inulin [3].

We aimed to hydrolyze the inulin in fermentative method and obtaining fructose syrup. As a research object, we chose the topinambur, one of the richest plants for inulin.

To compare the experimental results, the contents of the new collection of the topinambur "Mo'jiza" (kind of topinambur ) - total sugars, protein, solids and mineral elements (gray matter) was included in a table with the main species - "Fayz-baraka", which we learned.

Table1. Chemical composition of Fayz-baraka and Mo'jiza types of topinambur

\begin{tabular}{|l|l|c|c|c|}
\hline № & $\begin{array}{l}\text { Topinambur } \\
\text { varieties }\end{array}$ & $\begin{array}{c}\text { № General } \\
\text { Carbohydrates } \\
\%\end{array}$ & $\begin{array}{c}\text { Amount } \\
\text { of Inulin } \\
\%\end{array}$ & $\begin{array}{c}\text { Proteins, } \\
\%\end{array}$ \\
\hline 1 & Fayz-baraka & 19,2 & 12,3 & 1,6 \\
\hline 2 & Mo'jiza & 18,7 & 11,9 & 1,2 \\
\hline
\end{tabular}

As can be seen from the table, when we study of the chemical composition of the two types of topinambur, it was found that in the category "Fayz-baraka" was rich in inulin and carbohydrates compared to the "Mo'jiza" and "Fayzbaraka" was chosen as the research object.

The choice of an inulin container in production and the production of fructose syrup from this plant is the most important criterion for our research. The average weight of the type "Fayz-baraka" is $80 \mathrm{~g}$ and it is not difficult to establish processes of separating juice and extraction.

It is known from the literature that inulin $(\mathrm{C} 6 \mathrm{H} 10 \mathrm{O} 5) \mathrm{n}$ is located in crystalline form in the cells of the topinambur and other parts, easily dissolved in hot water (80-90oC), i.e. extracted.

Therefore, in the next step, in order to isolate the inulin from the tuber-crop of topinambur, is crushed, then extractive substances, including inulin isolated at $80-85 \mathrm{oC}$ 20-30 min. The result was cooled and it was filtered and the acidity level of the-prepared extract was determined to be $19 \%$ in the amount of carbohydrates. The resulting extract was sterilized in tubes for $30 \mathrm{~min}$ at a pressure of $0.5 \mathrm{~atm}$. The sediment and the clear part of the extract were separated into two fractions in the method of purification. The total carbohydrate content of the extract was $25-27 \%$. From the following extracts we used in the next experiments as to grow microorganisms and succeed in the effect of inulinase enzymes and to use fructose juice to conserve tubers. 
As known, fungi and yeasts between microorganisms are actively produce inulinase enzyme in an inulin feeding environment. Therefore, in this study, we have selected the yeast Saccharomyces cerevisiae-4 and the fungus Aspergillus oryzae-5 from the active ingredients of inulinase enzyme.

For these elements, we have prepared a nutritional environment according to their nature. In particular, the main ingredient for the yeast Saccharomyces cerevisiae is the topinambur extract which is the inulin-containing substrate as the only source of carbohydrate, and phosphorus and nitrogen sources are added at a rate of $1.0 \%$. Whole mass content Urea salt $0.25 \%$, diammonium phosphate $0.25 \%$, magnesium sulfate $0.1 \%$, ammonium sulphate $0.1 \%$, topinambur extract $30 \%$, was increased with water $250 \mathrm{ml}$.

The basis of the nutritional environment for Aspergillus oryzae was the Chapek artificial environment, and used extract of bud of the topinambur as a single carbon source. Sodium nitrate $0.05 \%$, potassium hydrophosphate $0.025 \%$, potassium chloride $0.012 \%$, iron sulfate $0.00025 \%$, magnesium sulfate $0.012 \%, 0.5 \%$, topinambur extract $30 \%$ and total mass increased with water to $250 \mathrm{ml}$.

In order to obtain fructose juice from the synthesis of Inulinase and topinambur extract, we added 2 pcs of tubes with $500 \mathrm{ml}$ from $250 \mathrm{ml}$ nutritional environment containing only the topinambur extract and 2 pcs of tubes with $500 \mathrm{ml}$ from $250 \mathrm{ml}$ with extracts of complex topinambur extract and the tubes were sterilized.

In accordance with these prepared nutritional environment, the Saccharomyces cerevisiae yeast and Aspergillus oryzae fungi have been inoculated. Then the seeds are grown in the electric circuit (at speeds of $200 \mathrm{rpm}$ ) for 5 days at $32{ }^{\circ} \mathrm{C}$, samples were taken every 24 hours, and biomass accumulation in the cultural environment, changes in $\mathrm{pH}$ environment, inulinase, protease, enzyme activity, fructose and protein was identified. The obtained results are included in Table 2.

The dynamics of the initial and the subsequent levels of fructose in the samples taken from these nutritional

Table 2: The results of the growing Aspergillus oryzae and Saccharomyces cerevisiae in nutritional environment which enriched with natural and minerals

\begin{tabular}{|c|c|c|c|c|c|c|}
\hline $\begin{array}{c}\text { Microorganisms } \\
\text { sowings and their } \\
\text { cultivated environment }\end{array}$ & $\begin{array}{l}\text { The interval } \\
\text { of growing } \\
\text { time } \\
\text { hour }\end{array}$ & $\begin{array}{l}\text { The amount of } \\
\text { biomass in } 10 \\
m l \text { of nutritional } \\
\text { environment, } g\end{array}$ & $\begin{array}{l}\text { Inulinase } \\
\text { enzyme } \\
\text { activity one } \\
/ m l\end{array}$ & $\begin{array}{l}\text { The amount of } \\
\text { Fructose in } \\
\text { nutritional } \\
\text { environment, } \\
\mathrm{mg} / \mathrm{ml}\end{array}$ & $\begin{array}{c}\text { Amount of } \\
\text { proteins in } \\
\text { nutritional } \\
\text { environment, } \\
\mathrm{mg} / \mathrm{ml}\end{array}$ & $\begin{array}{c}\text { Protease } \\
\text { enzyme } \\
\text { activity one } \\
\text { /ml }\end{array}$ \\
\hline \multirow{5}{*}{$\begin{array}{l}\text { Aspergillus oryzae } \\
\text { (natural extract) }\end{array}$} & 24 & 0,7 & 26,6 & 12 & 18,5 & 0,056 \\
\hline & 48 & 0,82 & 80 & 32 & 22,7 & 0,065 \\
\hline & 72 & 0,93 & 53,3 & 24 & 8,1 & 0,072 \\
\hline & 96 & 1,1 & 31,1 & 19 & 3,9 & 0,083 \\
\hline & 120 & 1,1 & 16,3 & 5 & 1,6 & 0,094 \\
\hline \multirow{4}{*}{$\begin{array}{l}\text { Saccharomyces } \\
\text { cerevisiae } \\
\text { (natural extract) }\end{array}$} & 24 & 0,44 & 20 & 11 & 12,7 & 0,051 \\
\hline & 48 & 0,67 & 37,7 & 27 & 17,2 & 0,064 \\
\hline & 72 & 0,76 & 82,2 & 34 & 6,4 & 0,078 \\
\hline & 96 & 0,78 & 56,4 & 17 & 6,12 & 0,086 \\
\hline $\begin{array}{l}\text { Retrieval Number: } 1114707 \\
\text { DOI : 10.35940/ijitee.I1 } 147\end{array}$ & $\begin{array}{l}9 / 19 \odot B E I E S P \\
\$ 219\end{array}$ & & \multicolumn{3}{|c|}{$\begin{array}{l}\text { Published By: } \\
\text { Blue Eyes Intelligence Engineering } \\
\& \text { Sciences Publication }\end{array}$} & \\
\hline
\end{tabular}

environments and the dynamics of microorganisms were studied in the growth dynamics of both cultures. The results showed that the fructose disintegration rate was reduced to $0.32 \mathrm{mg} / \mathrm{ml}$ in 48 hours, and $0.30 \mathrm{mg} / \mathrm{ml}$ in 72 hours, due to acceleration of the inulin hydrolysis by the Aspergillus oryzae-5 in the extracted medium without the addition of other nutrients, with a sharp decrease in fructose volume from 96 hours was observed. Hydrolysis of the insulin has high rate in 72 hours due to the inulin synthesis of Saccharomyces cerevisiae and the rate of fructose was 0.34 $\mathrm{mg} / \mathrm{ml}$, the decrease observed from the 96th hour after growth.

The inulin disintegration process in the liquid of cereals which are grown in the nutritional environment of mineral salt complex can be explained by the amount of extract of the topinambur extract that the natural extracts are slightly lower than the cultural fluid and have low indices.

In experimental variants, the decrease in the amount of fructose is associated with its fungal consumption, and the amount of fructose achieved at the beginning of the cycle (48-72 hours) does not occur at the subsequent stages of the process.

It's known that, proteolithic enzymes have the ability to break proteins in the nutritional environment. Increasing the amount of proteolithic enzymes in 4 different nutritional environments is one of the main factors leading to the decline in protein content in the next few days. We can observe the decrease in the amount of protein content of Aspergillus oryzae fungus which is grown in the nutritional environment was $22.7 \mathrm{mg} \mathrm{ml}$ for the 2nd day and in the 5th day for 11.5 times, and in mineral nutrition enriched in the same day by 5.08 times. In the tubes that Saccharomyces cerevisiae yeast inoculated protein content decreased in 5.3 times in natural extracts and 4.4 times in mineral enrichment in the following days compared to the initial amount of protein. 


\begin{tabular}{|c|c|c|c|c|c|c|}
\hline & 120 & 0,77 & 22,6 & 6 & 3,25 & 0,099 \\
\hline \multirow{5}{*}{$\begin{array}{l}\text { Aspergillus oryzae } \\
\text { (in nutritional } \\
\text { environment enriched } \\
\text { with mineralized } \\
\text { enzymes) }\end{array}$} & 24 & 0,39 & 17,7 & 7 & 3,6 & 0,034 \\
\hline & 48 & 0,49 & 24,4 & 22,7 & 11,2 & 0,042 \\
\hline & 72 & 0,55 & 20 & 23 & 11,7 & 0,051 \\
\hline & 96 & 0,56 & 15,4 & 16,5 & 5,8 & 0,059 \\
\hline & 120 & 0,55 & 11,3 & 4 & 2,3 & 0,059 \\
\hline \multirow{5}{*}{$\begin{array}{c}\text { Saccharomyces } \\
\text { cerevisiae } \\
\text { (in nutritional } \\
\text { environment enriched } \\
\text { with mineralized } \\
\text { enzymes) }\end{array}$} & 24 & 0,13 & 15,5 & 6 & 3,7 & 0,038 \\
\hline & 48 & 0,19 & 26,6 & 9 & 10,2 & 0,047 \\
\hline & 72 & 0,22 & 37,7 & 17,2 & 5,3 & 0,055 \\
\hline & 96 & 0,23 & 23,7 & 8 & 4,4 & 0,061 \\
\hline & 120 & 0,21 & 12,4 & 4,3 & 2,3 & 0,061 \\
\hline
\end{tabular}

Enrichment of the activity of inulinase enzymes was observed during the second day of cultivation of microorganisms in Aspergillus oryzae fungus tubes, i.e. if it was $80 \mathrm{mg} / \mathrm{ml}$ in the 48 -hour of natural environment it made up $24.4 \mathrm{mg} / \mathrm{ml}$ in natural environment enriched with minerals. In the next few days, we can see from the table that the activity of the enzyme declined. On the second day of cultivation of the microorganisms of the fungus in the natural extract of the topinambur, the activity of inulinase enzymes was maximized, the activity of enzyme decreased by 5 times over the 5 th day. In the environment enriched with minerals, the enzyme activity decreased 2.1 times in the same day.

In the tubes which Saccharomyces cerevisiae yeast inoculated, inulinase enzyme activity was maximized in 3 days, i.e. if it was $82,2 \mathrm{unit} / \mathrm{ml}$ in 3 days in natural nutritional environment and was $37.7 \mathrm{unit} / \mathrm{ml}$ in the environment enriched with minerals. That is, it can be observed that it decreased for 3.6 times in natural extracted environments and in mineral enrichment less than 3 times.

Accordingly, we can see that the number of proteins enlarged when the days of enzymes were active and they decreased in the next days. This process is due to the activation of protease enzymes, which is caused by the microorganisms that proteins are expelled by protease enzymes.

Due to increased biomass (microorganism cells) the acidity of the environment decreases. In natural extract tubes, the amount of biomass was found to be 5 times lower than the biomass in the nutritional environment which enriched with minerals. We can see protease, inulinase, is highly effective in the enzyme activity, and the amount of protein in the natural nutritional environment is several times higher. This process can be explained by the amount of topinambur extract in enriched nutritional environment is small and the disadvantage of the environment for the development of microorganisms. It is proofed that microorganisms can develop well in the natural environment.

The above information can be summarized as follows:

1. It is determined by the experiments that the kind of topinambur "Fayz Baraka" is reach for chemical composition than the kind "Mo'jiza" which are grown in Uzbekistan.

2. It is determined that in the natural nutritional environment the microorganisms are well developed and more produtients can be found in the nutritional enriched environment.

3. Experiments show that inulinase enzyme activity was maximized in tubes in which Aspergillus oryzae fungus was cultivated in 2 days and in tubes which Saccharomyces cerevisiae yeast was inoculated in 3 days.

4. Almost in all nutritional environments, the amount of protein is increased initially proteinase enzymes increased the protein levels decreased.

5. Using inulinase enzyme isolated by microorganisms in the process of inulin disintegration, it is possible to obtain fructose-rich syrups and this syrup can be used in the form of saccharose.

\section{REFERENCES}

1. Thai Ha D. Characterization of inulin hydrolyzing enzyme(s) in commercial glucoamylases and application in acid production from Jerusalem artichoke tubers (Jat) / Thai Ha Dao, Jian Zhang, Jie Bao // Bioresource technology. 2013. - Vol.148. - P. 157-162.

2. Dzhanikulova U.B., Akhmedova Z.R. Enzymatic method of producing fructose syrup for the food industry // Uzbek Biological Journal. - Tashkent, 2006. -№1. -P. 132135.

3. Nazarenko, M.N., Barkhatova, M.A. Kozhukhova, R.A. Drozdov Investigation of the process of fermentation of inulin in the production of fructose-glucose syrup // Polythematic network electronic scientific journal of the Kuban State Agrarian institute - Krasnodar, 2014. - №04 (098). 